\title{
A Case of Offspring Adoption in Free-Ranging Polar Bears (Ursus maritimus)
}

\author{
S.N. ATKINSON,${ }^{1}$ M.R.L. CATTET, ${ }^{2}$ S.C. POLISCHUK ${ }^{1}$ and M.A. RAMSAY ${ }^{1}$
}

(Received 6 July 1995; accepted in revised form 5 October 1995)

\begin{abstract}
During a study of the reproductive ecology of polar bears (Ursus maritimus) in western Hudson Bay (Canada), we documented a case of litter adoption. In an eight-month period, a ten-year-old adult female lost a litter of two cubs-ofthe-year and adopted three other cubs-of-the-year. This is the first reported case of natural offspring adoption in polar bears, and its significance as a reproductive strategy is unknown. Nevertheless, the observation raises questions regarding the social circumstances under which adoption may occur and the benefits or costs to maternal fitness in a solitary mammal such as the polar bear.
\end{abstract}

Key words: polar bear, Ursus maritimus, litter adoption, maternal fitness

RÉSUMÉ. Au cours d'une étude portant sur l'écologie de la reproduction des ours polaires (Ursus maritimus) dans la partie ouest de la baie d'Hudson (Canada), on a documenté un cas d'adoption de litière. Au cours d'une période de huit mois, une femelle adulte de dix ans a perdu sa litière de deux petits âgés de moins d'un an et adopté trois autres petits de l'année. Cetévénement est le premier cas d'adoption naturelle que l'on ait rapporté chez l'ours polaire, et on n'en a pas encore mesuré l'importance en tant que stratégie de reproduction. L'observation soulève cependant des questions concernant les conditions sociales dans lesquelles peut se produire l'adoption et les avantages ou les coûts pour la santé maternelle chez un mammifère solitaire tel que l'ours polaire.

Mots clés: ours polaire, Ursus maritimus, adoption de litière, santé maternelle

Traduit pour la revue Arctic par Nésida Loyer.

The polar bear (Ursus maritimus) is a large, solitary carnivore that inhabits arctic and subarctic sea ice and adjacent terrestrial regions (DeMaster and Stirling, 1981). This sexually dimorphic mammal appears to have a polygynous mating system, in which parental care is provided exclusively by females (Ramsay and Stirling, 1986). Relatively little is known, however, about the reproductive strategies of female polar bears (Ramsay and Stirling, 1988). Here we report an observation of offspring adoption in this species.

We routinely sampled free-ranging polar bears at different seasons as part of a long-term study of polar bears in the Cape Churchill region of western Hudson Bay, Canada. A Bell 206B helicopter was used to search for and capture the polar bears. Animals older than one year were anaesthetized by remote injection of Telazol $^{\circ}$ (A.H. Robins Co., Richmond, VA, U.S.A.) using standard methods (Stirling et al., 1989). Cubs-of-the-year were anaesthetized by hand or jab-pole injection of Telazol ${ }^{\oplus}$. Unmarked bears were assigned a unique identifying number, which was applied as a tattoo on both left and right buccal surfaces of the upper lip and also as two Delrin ${ }^{\circledR}$ ear tags. Adult females were fitted with very high frequency (VHF) radio transmitters to allow relocation. A vestigial first premolar tooth was extracted from adults and subadults for age determination (Grue and Jensen, 1979).
After research activities were complete, we left the bears, which were allowed to recover normally.

On 5 March 1994, a ten-year-old adult female polar bear was captured as she emerged from an over-winter maternity den with her litter of two 3-month-old cubs. The mother, identified by numerically coded ear tags and lip tattoos applied during previous captures, was lactating heavily. Both cubs were fitted with uniquely identifying ear tags and lip tattoos. On 28 October 1994, after presumably spending the spring and early summer hunting seals on the sea ice, the same adult female was relocated by radio telemetry and again captured as part of our longitudinal study. She was still lactating but was now accompanied by three 10-month-old cubs, none of which had ear tags or lip tattoos or displayed any physical evidence of having been previously captured. Over the following month, this family group was resighted on two separate occasions. While it is not unusual for a female bear to lose an entire litter of new cubs within their first year of life (Derocher and Stirling, 1992), this is, to the best of our knowledge, the first reported case of natural adoption in polar bears.

Non-offspring nursing (i.e., the provision of milk for another individual's offspring) is not uncommon among mammals, but it is most often observed in species which rear

\footnotetext{
${ }^{1}$ Department of Biology, University of Saskatchewan, Saskatoon, Saskatchewan S7N 5E2, Canada

${ }^{2}$ Department of Veterinary Pathology, Western College of Veterinary Medicine, University of Saskatchewan, Saskatoon,

Saskatchewan S7N 5B4, Canada

(C) The Arctic Institute of North America
} 
their offspring within discrete social groups or large aggregations (Pusey and Packer, 1994). In these instances, members of a group are sometimes closely related, or there may be reciprocal benefits to communal rearing (Packer et al., 1992). Adoption, however, is a particularly extreme form of non-offspring nursing that, for solitary species such as the polar bear that exhibit a relatively long lactation period, could have significant costs in terms of maternal fitness (CluttonBrock et al., 1989). Depending upon its timing relative to the annual mating period (April-May), the loss of a litter would normally permit an adult female polar bear to commence a new reproductive cycle within a year. In contrast, the adoption and eventual weaning of cubs could delay further reproduction for at least two and possibly up to three years (Ramsay and Stirling, 1988; Derocher and Stirling, 1992), thereby considerably reducing lifetime reproductive success.

Alternatively, a number of potential benefits may be associated with adoption in mammals (Riedman, 1982). Although lifetime reproductive success might be reduced in animals that adopt offspring, maternal inclusive fitness could be enhanced if the adopted individuals were closely related to their foster mother (Hamilton, 1964). Unfortunately, in the case we report here, the degree of relatedness between the adult female and her adopted cubs could not be determined. Although polar bears do not appear to maintain stable home ranges, but instead wander over exceptionally large areas during winter and spring in search of prey (Ramsay and Stirling, 1986; Garner et al., 1990), in the western Hudson Bay population pregnant polar bears do tend to enter maternity dens in the vicinity of their birthplace and return to those same regions in the summers when they are accompanied by cubs (Ramsay and Andriashek, 1986). Thus, it is possible that during the summer and autumn months polar bears in our study population may have an increased opportunity to encounterclosely related individuals (i.e., mother, sisters, aunts). Proximity of kin would tend to increase the likelihood of meeting Hamilton's (1964) conditions for the evolution of apparently altruistic behaviour. More subtly, even if a mother is unrelated to her adopted litter, experience gained by providing care to adopted cubs might increase her success in future reproductive attempts and outweigh the costs of delaying reproduction (Riedman, 1982; Riedman and Le Boeuf, 1982; Sydeman et al., 1991). This ten-year-old female bear, however, was known to have had at least three litters prior to the adoption event. Rearing of the adopted litter might thus have improved parenting skills only to a limited extent in this already experienced female.

Rather than reflecting an adaptive behavioral strategy, adoption may in some cases be viewed as a "misplaced reproductive function" or reproductive error by a foster parent (Williams, 1966; Riedman, 1982). Particularly during the early stages of lactation, female polar bears that have recently lost their offspring may still be hormonally primed for providing parental care and therefore prone to adopting any available cubs they encounter. Furthermore, as polar bears do not typically raise their offspring under social conditions, selection pressures for a well-developed mechanism of mother-offspring recognition may be relatively weak (Breed and Bekoff, 1981; Holmes, 1990). Consequently, the potential for misidentification and adoption of non-kin may be significant at times when the offspring of a number of females are in close proximity. In brown bears (U. arctos), cub adoptions sometimes occur during seasonal salmon runs, when family groups congregate to feed (Erickson and Miller, 1963; Barnes and Smith, 1993). However, unlike the incident we describe here, reported adoptions in brown bears have not involved the replacement of an entire litter (Craighead et al., 1969; Barnes and Smith, 1993). Because the polar bears of western Hudson Bay are forced on shore each summer by the complete melting of the sea ice, they may briefly encounter higher densities of conspecifics than polar bears further north (Latour, 1981). Similar high densities of polar bears on land are also known to occur in Svalbard (Larsen, 1985) and Wrangel Island (Uspenski and Kistchinski, 1972).

Routine determination of the relatedness of cubs to putative mothers using microsatellite genetic markers (Paetkau et al., 1995) or other molecular fingerprinting techniques might allow a quantitative assessment of frequency of adoption within polar bear populations. Other incidences of cub adoption among polar bears have been observed in Canada, but none have previously been documented. Since our observation, two cubs were captured with an 11-year-old female on 27 April 1994, in the Canadian Arctic islands. Almost a year later, on 10 May 1995, these same two cubs were recaptured in the same area, accompanied by a different adult female (M. Taylor, pers. comm. 1995). Despite the apparent rarity of adoption in polar bears, its occurrence raises questions about the social conditions under which it takes place, its timing relative to the mating period and stage of lactation, and finally its effects on maternal fitness in this supposedly solitary mammal.

\section{ACKNOWLEDGEMENTS}

Financial support was received from the Natural Sciences and Engineering Research Council of Canada, the Medical Research Council of Canada, the National Science Foundation of the U.S.A., Environment Canada, the Boone and Crockett Club, J. Hochglaube, The University of Saskatchewan, and the Northern Scientific Training Program of Canada. We gratefully acknowledge the support of the Manitoba Department of Natural Resources and the Churchill Northern Studies Centre. We thank J.W. Lentfer and two anonymous reviewers for constructive comments on an earlier version of the manuscript.

\section{REFERENCES}

BARNES, V.G., Jr., and SMITH, R.B. 1993. Cub adoption by brown bears, Ursus arctos middendorfii, on Kodiak Island, Alaska. Canadian Field-Naturalist 107:365-367.

BREED, M.D., and BEKOFF, M. 1981. Individual recognition and social relationships. Journal of Theoretical Biology 88:589-593. 
CLUTTON-BROCK, T.H., ALBON, S.D., and GUINNESS, F.E. 1989. Fitness costs of gestation and lactation in wild mammals. Nature 289:487-489.

CRAIGHEAD, J.J., HORNOCKER, M.G., and CRAIGHEAD, F.C., Jr. 1969. Reproductive biology of young female grizzly bears. Journal of Reproduction and Fertility 6:447-475.

DEMASTER, D.P., and STIRLING, I. 1981. Ursus maritimus. Mammalian Species 145:1-7.

DEROCHER, A.E., and STIRLING, I. 1992. The population dynamics of polar bears in western Hudson Bay. In: McCullough, D.R., and Barrett, R.H., eds. Wildlife 2001: Populations. London: Elsevier Applied Science. 1150-1159.

ERICKSON, A.W., and MILLER, L.H. 1963. Cub adoption in the brown bear. Journal of Mammalogy 44:584-585.

GARNER, G.W., KNICK, S.T., and DOUGLAS, D.C. 1990. Seasonal movements of adult female polar bears in the Bering and Chukchi seas. International Conference on Bear Research and Management 8:219-226.

GRUE, H., and JENSEN, B. 1979. Review of the formation of incremental lines in tooth cementum of terrestrial mammals. Danish Review of Game Biology 11:1-48.

HAMILTON, W.D. 1964. The genetical evolution of social behavior. Journal of Theoretical Biology 7:1-51.

HOLMES, W.G. 1990. Parent-offspring recognition in mammals: A proximate and ultimate perspective. In: Krasnegor, N.A., and Bridges, R.S., eds. Mammalian parenting: Biochemical, neurobiological, and behavioral determinants. Oxford: Oxford University Press. 441-460.

LARSEN, T. 1985. Polar bear denning and cub production in Svalbard, Norway. Journal of Wildlife Management 49:320326.

LATOUR, P.B. 1981. Spatial relationships and behavior of polar bears (Ursus maritimus Phipps) concentrated on land during the ice-free season of Hudson Bay. Canadian Journal of Zoology 59:1763-1774.
PACKER, C., LEWIS, S., and PUSEY, A.E. 1992. A comparative analysis of non-offspring nursing. Animal Behaviour 43:265281.

PAETKAU, D., CALVERT, W., STIRLING, I., and STROBECK, C. 1995. Microsatellite analysis of population structure in Canadian polar bears. Molecular Ecology 4:347-354.

PUSEY, A.E., and PACKER, C. 1994. Non-offspring nursing in social carnivores: Minimizing the costs. Behavioural Ecology $5: 362-374$

RAMSAY, M.A., and ANDRIASHEK, D.S. 1986. Long distance route orientation of female polar bears (Ursus maritimus) in spring. Journal of Zoology (London) 208:63-72.

RAMSAY, M.A., and STIRLING, I. 1986. On the mating system of polar bears. Canadian Journal of Zoology 64:2142-2151.

RAMSAY, M.A., and STIRLING, I. 1988. Reproductive biology and ecology of female polar bears (Ursus maritimus). Journal of Zoology (London) 214:601-634.

RIEDMAN, M.L. 1982. The evolution of alloparental care and adoption in mammals and birds. Quarterly Review of Biology 57:405-435.

RIEDMAN, M.L., and LE BOEUF, B.J. 1982. Mother-pup separation and adoption in northern elephant seals. Behavioural Ecology and Sociobiology 11:203-215.

STIRLING, I., SPENCER, C., and ANDRIASHEK, D.S. 1989. Immobilization of polar bears (Ursus maritimus) with Telazol in the Canadian Arctic. Journal of Wildlife Diseases 24:159-168.

SYDEMAN, W.J., HUBER, H.R., EMSLIE, S.D., RIBIC, C.A., and NUR, N. 1991. Age-specific weaning success of northern elephant seals in relation to previous breeding experience. Ecology 72:2204-2217.

USPENSKI, S.M., and KISTCHINSKI, A.A. 1972. New data on the winter ecology of the polar bear (Ursus maritimus Phipps) on Wrangel Island. International Conference on Bear Research and Management 2:181-197.

WILLIAMS, G.C. 1966. Adaptation and natural selection. Princeton: Princeton University Press. 307 p. 